\title{
HUMAN CAPITAL AS A ESSENTIALS ELEMENT OF INTELLECTUAL CAPITAL
}

\author{
KATARZYNA ZIOŁO \\ University of Szczecin, Faculty of Management and Economics of Services, POLAND \\ e-mail: katarzyna.ziolo@wzieu.pl
}

\author{
RECEIVED \\ 10 December 2018 \\ ACCEPTED \\ 28 December 2018 \\ JEL \\ CLASSIFICATION \\ M2, M50, M53
}

KEYWORDS

intellectual capital, human capital, organizational capital, customer capital, investments, raising competence

ABSTRACT

On the basis of literature, the author presents the essence of human capital as a key component of intellectual capital and strategic resource of the organization. The paper demonstrates the role of human capital that it plays in today's turbulent reality. The first part presents the concept of human capital, with various shots and the characteristics of its components. In the second part focuses on the essence of human capital and actions needed for its development. The purpose of this paper is to characterize the concept of human capital, to indicate its role in relation to intellectual capital, and an attempt to answer the question, what actions can be taken to improve it. The research paper is of demonstration character and it uses a critical analysis of the national and foreign literature on the subject. The paper uses monographs, collective papers, websites, articles and reports. A critical analysis of literary shows that human capital is the foundation of competitive advantage organizations, and investments in its improvement are necessary.

\section{Introduction}

Human capital gives organizations the opportunity to create innovative goods and services, processes and technologies. It creates the right conditions for the development of information systems and databases. It is the source of maintaining good, difficult to reproduce relations with clients, based on mutual respect, patience and loyalty. It also allows organizations to gain new markets and acquire new business partners. Good quality of human 
capital is ensured by the high quality of services, products and faster production. It brings benefits associated with a better knowledge flow in the organization and a more accurate understanding of the goals organization wants to achieve. Human capital is the real wealth of all organizations. That is why it is so important for organizations to take actions that will develop this capital and which at the same time can provide success to market players. Activities aimed at improving human capital can be undertaken both by employers and employees themselves. These activities should be carried out in a systematic way, and their capability should correspond to the needs of employees and organizational strategies. The purpose of this paper is to characterize the concept of human capital, to indicate its role in relation to intellectual capital, and to discuss the actions that can be taken to improve it.

\section{Components of intellectual capital}

Intellectual capital is one of the most important assets that create the value of an organization, and thus significantly affects the building of its competitive advantage. The elements of this capital include: loyal customers, talented employees, copyrights and all organizational knowledge related to the management method, its history and organizational culture.

Intellectual capital is understood as assets such as knowledge, collective competences, reputation of the organization, customers, brand value and patents that can not be measured by traditional accounting methods, but nevertheless bring benefits to the company. Market position, reputation and loyal clients, achievements, recognition, contacts, partners and support are different aspects of intellectual capital (Tiwana, 2003, p. 61). E. Skrzypek for the most important element of intellectual capital, assumes knowledge useful for the organization and distinguishes three of its components (Skrzypek, 1999, p. 5):

- employee capital including the knowledge of individual employees, which affects the ability to meet customer needs,

- structural capital including business processes and systems existing in the company,

- market capital including customer relations.

According to the definition of J. Fitz-Enz, intellectual capital includes two categories: intellectual property of the company and a complicated combination of processes and cultures, combined with a network of various types of relationships and human capital (Fitz-Enz, 2001, pp. 23-24). A. Brooking understands intellectual capital even more. According to her, intellectual capital is: marketable assets (e.g. market position, company name, distribution channels), intellectual property (assets protected by law) and human assets (knowledge and skills of people) and infrastructure assets (management philosophy, communication, information systems (Brooking, 1999, pp. 16-21). In the literature on the subject, there are many definitions of intellectual capital, but the most-recognized one seems to be presented by L. Edvinsson and M.S. Malone. They present intellectual capital as being based on two components: human capital and structural capital. According to them, human capital is the combined knowledge, innovation, skills and abilities of individual employees of the organization necessary for the efficient performance of tasks. Structural capital, on the other hand, is computer hardware, software, databases, patents and trademarks. It can be owned by the company and can be sold (Edvinsson, Malone, 2001, p. 17). L. Edvinsson is the creator of the intellectual capital development mission at Skandia, in which he focused mainly on the identification and distinction of intangible assets of the organization. Skandia was the first company that issued an annual report on intellectual capital and distinguished the director's position related to intellectual development in the organizational structure. A detailed division of intellectual capital is shown in Figure 1. 


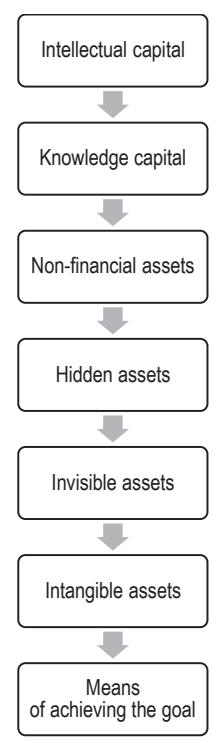

Figure 1. Section of intellectual capital

Source: Edvinsson, Malone (2001), p. 18.

According to the concept of Edvinsson and Malone, intellectual capital may take permanent form (e.g. patents), as well as a variable form (e.g. skills of employees). In addition, it is created through the co-operation of the knowledge process and can be the end product of the knowledge transformation process or the system for creating enterprise value. This last property is particularly important for building the competitive advantage of the organization. In the face of a reality in which the product plays a lesser and lesser role (its features can be copied), intellectual capital becomes the area of investment and the main source of enterprise development. The value of an organization is built as a result of interaction that occurs between all elements of intellectual capital, and does not result directly from the activity of one of them. It is not enough to build the value of an enterprise if one or two components of intellectual capital are well developed. If the remaining components are weak, then the organization won't be able to transform intellectual capital into value.

This interaction and mutual integration of intellectual capital elements is dynamic, continuous and expansive. The more the circles overlap each other (Figure 2), the higher value is created. Therefore, the organization's goal is to increase the number of interrelationships and relations between all elements of human capital, which leads to the maximization of the company's value (Kaczmarek, 2005, p. 321).

Organizational capital as an element of intellectual capital, also called structural, is a knowledge that has been acquired and implanted in the structure of the organization, its processes and culture (Petrash, 1996, p. 38). The components of this capital are:

1. Intellectual property, including:

- patents,

- copyrights,

- design rights, 
- trade secret,

- trademark,

- distinguishing services.

2. Infrastructural assets, including:

- management philosophy,

- organizational culture,

- management processes,

- information system,

- system of connections,

- financial relations.

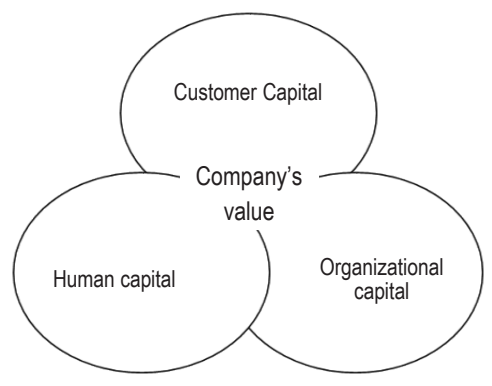

Figure 2. The relationship between intellectual capital and the value of the company

Source: Petrash (1996), p. 38.

The second element of intellectual capital - clients' capital is connected with the company's relations and contacts with its environment. The components of this capital include the image of the organization on the market, relations with suppliers, distribution channels and customer loyalty. According to the author, the most important element of intellectual capital is human capital, which enables building relationships with clients, strengthening the image, or creating relationships with other entities on the market.

\section{The essence of human capital and its development}

Due to the fact that the intellectual capital of the organization must change over time and must be multiplied, the necessary condition for this is human presence and human action, that is human capital. Thanks to the knowledge, skills and attitudes presented by people, it is possible to build a lasting competitive advantage of the organizations and societies. If the competitors of the organization are not able to duplicate or imitate employees, then they can develop and achieve success on the market. Therefore, human capital is perceived as the most important component of intellectual capital. It is the people and the skills and their features that allow them to "keep up with the times", and thus provide prosperity to all economies (Jamka, 2011, p. 143). The concept of human capital is explained and understood in various ways, including: 
a) a set of properties inherent in people, such as: knowledge, skills, psychological traits, health, behaviors with a certain value that can be a source of future income for both an employee and an organization (Leksykon zarządzania, 2004, p. 193);

b) accumulated knowledge, education, qualifications, skills, abilities and readiness to increase the economic potential possessed by its owners and society as a whole (Marciniak, 2002, p. 7);

c) a resource of knowledge and skills of a certain value being a source of future earnings or satisfaction, a renewable and constantly increasing human potential (Grodzicki, 2003, p. 46);

d) the ability to generate new economic values, which is determined by many factors, including: knowledge and skills, health and vital energy, as well as recognized values, culture, tradition (Marciniak, 2002, pp. 12-13);

e) overall human skills, but also his mental and intellectual abilities, which can be used by him in the process of active participation in business life (Domański, 1993, p. 32).

Human capital management focuses on researching employee attitudes and competences and developing those that are necessary to achieve the company's strategic goals. In addition, this management is also related to the development of a system of knowledge sharing among employees, as well as the creation of an appropriate motivating system that will stimulate them to acquire and develop knowledge and skills necessary for the enterprise's needs.

The quality of human capital at the macro level and at the organizational level is influenced by such investments as (Rutkowska, 2016, pp. 339-346):

- vocational education and training as well as experience gained during work,

- action in the field of lifelong learning of adults,

- health care services affecting life expectancy, physical fitness and people's inclination to work intensively,

- gathering information and scientific research, in particular relating to the creation of quality of human capital and the quality of life of the society,

- effort put into the education of the young generation by individuals,

- adequate free time necessary for the regeneration of work capacity,

- economic activity of households to create human capital of family members and society as a whole,

- ethical factors (social and individual value system) influencing pro-effective and prosocial attitudes of owners of human capital,

- factors of financial and structural depreciation of human capital for the economic development of the country.

High quality of human capital allows economies to absorb the modern technologies, thus ensuring economic and social growth. In addition, it contributes to the improvement of the quality of life of the society, increase of creativity and productivity of individuals, thus affecting the competitiveness of a given country. Therefore, investments in this type of capital seem necessary to deal with the rapidly changing environment and build modern societies. Also at the level of the organization, investments in human capital should be perceived as necessary for the company to be able to develop dynamically and build its position on the market.

Investing in a person should be treated by the employer with the same solicitude as investing in research and development. People have the ability to learn and constantly improve and more than other resources, contribute to 
the creation of enterprise added value (Rybak, 2003, p. 40). The appropriate quality of human capital enables the organization of:

- improving employee efficiency,

- implementation of the strategy,

- the use of opportunities from the environment,

- recognition and defense against threats.

For the development of human capital in the organization, it is essential to recognize the current and strategic training needs of the employees. The study of employees' needs allows for selection and the preparation of appropriate training, and thus contributes to a better acquisition of knowledge conveyed during training and omitting what employees know from practice or what has been passed on to them in other training.

According to Industry Report, U.S. companies spent over $\$ 90$ billion dollars on training and development activities in 2017, a year-over-year increase of $32.5 \%$. Average training expenditures for large companies increased from $\$ 14.3$ million in 2016 to $\$ 17$ million in 2017. Likewise, the number for small companies rose to $\$ 1$ million from $\$ 376,251$ in 2016. But midsize companies remained mostly fiat at \$ 1.5 million (2017 Training..., 2017). In addition to spending more on training, companies provided more hours of training in 2017. On average, employees received 47.6 hours of training per year, nearly 4 hours more than last year. Midsize companies provided the most hours of training this year at 54.3. Midsize service providers had the highest average number of hours overall (75.5).

As can be seen in the Report on Human Capital (Turek, Worek, 2015, pp. 67-112) employers' awareness of the need to invest in human capital increases (Figure 3).

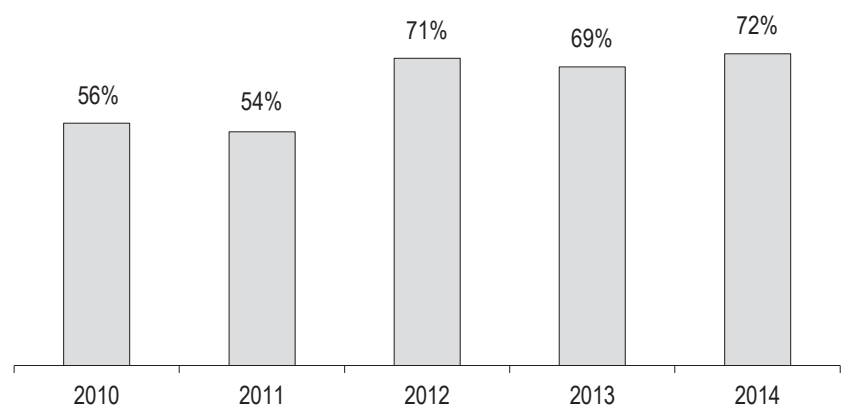

Figure 3. The percentage of employees declaring operate in the skills development for workers

Source: Turek, Worek (2015), pp. 67-112.

In $2014,72 \%$ of Polish companies and institutions declared a way to invest in the development of their employees. In absolute terms, it was about 1.4 million entities, while in 2011 and in 2012, approx. 1.2 million. Not only courses and trainings were taken into account, but also co-financing of education in vocational and secondary schools (basic vocational schools, technical schools, high schools), in higher education institutions (e.g. post-graduate studies, MBA, extramural studies), participation in conferences, seminars, workshops, subsidizing self-education of employees (e.g. purchase of books, magazines), as well as the application of the employee competence assessment system and individual employee development plans (Turek, Worek, 2015, pp. 89-104). 
In addition, more frequent investments in human capital were declared by larger entities - employing more than 250 employees (it was about $95 \%$ of all large entities). The smallest activity in the area of investments in employees was demonstrated by entities operating in trade, hotel and catering, as well as employers from the industry and mining sector, as well as construction and transport. Among various forms of improving competences, the most popular were the courses and optional training and self-education of employees. However, the least popular was the creation of individual development plans and co-financing of formal education. Unfortunately, there is no current data on this subject.

\section{Conclusions}

If the organization wants to face the challenges it faces, it should develop all the elements that make up intellectual capital. The component that requires the largest investment is human capital. Investing in this type of capital contributes not only to the development and success of the organization, but also has an impact on improving the quality of life of the society, increasing the competitiveness of economies and dynamic development of modern technologies. Employers have a large duty to improve the quality of human capital. Employees' competences and knowledge can then be increased through the participation of employees in training, courses, post-graduate studies or workshops. It is necessary to provide the employees with appropriate forms of development, tailored to their and organization's needs. The report quoted in the second part shows that not all employers perceive their role in building human capital. Many of them consider the skills of their employees as sufficient, and some assume that employees do not have time to participate in activities that raise their competences. Employers also prefer to invest in other related areas with the functioning of the organization and do not perceive that expenditures incurred for the improvement of employees can bring tangible benefits. Therefore, it is necessary to change the attitude of employers to invest in employees. To develop human capital, it is necessary to unleash employees' enthusiasm and openness to gain new experiences. It seems that the key to building human capital in society is the creation of attitude of activity and commitment to raising their potential.

\section{References}

Brooking, A. (1999). Corporate Memory. Strategies for Knowledge Memory. London: International Thomson Business Press.

Domański, S.R. (1993). Kapitał ludzki i wzrost gospodarczy. Warszawa: PWN.

Edvinsson, L., Malone, M.S. (2001). Kapitał intelektualny. Warszawa: Wydawnictwo Naukowe PWN.

Fitz-Enz, J. (2001). Rentowność inwestycji w kapitał ludzki. Kraków: Wolters Kluwer.

Grodzicki, J. (2003). Rola kapitału ludzkiego w rozwoju gospodarki globalnej. Gdańsk: Wydawnictwo Uniwersytetu Gdańskiego. 2017 Training. Industry report (2017). Retrieved from: https://trainingmag.com/trgmag-article/2017-training-industry-report.

Jamka, B. (2011). Czynnik ludzki we współczesnym przedsiębiorstwie: zasób czy kapitał. Warszawa: Wolters Kluwer business.

Kaczmarek, B. (2005). Kapitał intelektualny (wiedza) a kreowanie wizji przedsiębiorstwa. Nierówności Społeczne a Wzrost Gospodarczy, 7, 319-329.

Leksykon zarządzania (2004).Warszawa: Difin.

Marciniak, S. (2002). Perspektywy kapitału ludzkiego jako czynnika wzrostu gospodarczego Polski. Warszawa: Oficyna Wydawnicza Politechniki Warszawskiej.

Petrash, G. (1996). Dow's Journey to a Knowledge Value Management Culture. European Management Journal, 14, $145-162$.

Rutkowska, A. (2016). Istota kapitału ludzkiego i wybrane metody jego pomiaru. Retrieved from: http://jmf.wzr.pl/pim/2012_1_3_29.pdf. Rybak, M. (2003). Kapitał ludzki a konkurencyjność przedsiębiorstw. Warszawa: Poltext. 
Skrzypek, E. (1999). Wpływ zarządzania wiedzą na jakość. Problemy Jakości, 11, 4-9.

Tiwana, A. (2003). Przewodnik po zarządzaniu wiedzą. E-biznes i zastosowania CRM. Warszawa: Placet.

Turek, K., Worek, B. (2015). Kształcenie po szkole. Na podstawie badań instytucji i firm szkoleniowych, pracodawców i ludności zrealizowanych w 2014 roku w ramach V edycji projektu Bilans Kapitału Ludzkiego Edukacja a rynek pracy - tom III. Warszawa: PARP.

Cite this article aS: Zioło, K. (2018). Human capital as a essentials element of intellectual capital. European Journal of Service Management, 4 (28/2), 541-548. DOI: 10.18276/ejsm.2018.28/2-65. 